\title{
PENGARUH BERAT MOLEKUL KITOSAN TERHADAP FIKSASI KITOSAN PADA KAIN KAPAS SEBAGAI ANTIBAKTERI
}

\section{EFFECT OF CHITOSAN MOLECULAR WEIGHT TO CHITOSAN AFFIXATION ON COTTON FABRIC AS AN ANTIBACTERIAL AGENT}

\author{
Rizka Yulina, Wiwin Winiati, Cica Kasipah, \\ Wulan Septiani, Agus Surya Mulyawan, Tatang Wahyudi \\ Balai Besar Tekstil, Jalan Jenderal Ahmad Yani No. 390 Bandung \\ E-mail: texirdti@bdg.centrin.net.id
}

Tanggal diterima: 22 September 2014, direvisi: 24 Oktober 2014, disetujui terbit: 18 Nopember 2014

\begin{abstract}
ABSTRAK
Proses depolimerisasi kitosan telah dilakukan untuk memperoleh kitosan dengan berat molekul yang lebih rendah dan mengetahui sifat antibakterinya setelah difiksasi pada kain kapas. Proses depolimerisasi dilakukan dengan cara pemanasan menggunakan oven microwave disertai penambahan larutan garam elekrolit $\mathrm{NaCl}$ dan $\mathrm{CaCl}_{2}$. Variasi proses pemanasan dilakukan pada rentang daya microwave 300-800 watt dan rentang waktu selama 5-25 menit. Berat molekul kitosan ditentukan dari viskositasnya dan dihitung menggunakan persamaan Mark Houwink. Hasil depolimerisasi kitosan menggunakan pelarut campuran $\mathrm{CH}_{3} \mathrm{COOH} 1 \% / \mathrm{CaCl}_{2} 0,25 \mathrm{M}$ dengan rasio volume 7:3 dan rentang daya microwave 300-650 watt telah berhasil menurunkan berat molekul kitosan secara signifikan dari 171.790 Da hingga mencapai 59.746 Da. Hasil analisa terhadap spektra Fourier Transform Infra Red menunjukkan bahwa proses depolimerisasi kitosan tidak mengubah gugus fungsi dari kitosan. Fiksasi kitosan terdepolimerisasi dengan rentang berat molekul 59.746-79.570 Da pada kain kapas menghasilkan sifat antibakteri yang sangat baik yakni mencapai $99-100 \%$, sekalipun prosesnya diikuti dengan proses pencelupan warna. Hasil uji N-total menunjukkan bahwa kain kapas terfiksasi kitosan berat molekul 79.500 Da menghasilkan nilai N-total yang lebih tinggi dibandingkan dengan kitosan berat molekul 171.790 Da. Hasil kurva ketuaan warna menunjukkan bahwa kitosan BM rendah cocok (compatible) dengan zat warna reaktif yang digunakan pada proses pencelupan dan memberikan warna pada kain kapas yang lebih tua dibandingkan dengan kitosan BM tinggi dan tanpa kitosan.
\end{abstract}

Kata kunci: kitosan, depolimerisasi, sifat antibakteri, oven microwave

\section{ABSTRACT}

Depolymerization process of chitosan was done in order to get its lower molecular weight and understand its antibacterial properties after affixation on cotton fabric. Depolymerization process was done by heating the chitosan using microwave oven and electrolyte solution addition of $\mathrm{NaCl}$ and $\mathrm{CaCl}_{2}$. The heating process of chitosan varied in the microwave oven power range of 300-800 watt and the reaction time as long as 5-25 minutes. The molecular weight of chitosan was determined through its viscosity and calculated using the Mark Houwink equation. The chitosan depolymerization in mixed solution of $1 \% \mathrm{CH}_{3} \mathrm{COOH} / 0,25 \mathrm{M} \mathrm{CaCl}_{2}$, volume ratio of 7:3, and the microwave oven power of 300-650 watt had been successful in decreasing the molecular weight of chitosan from $171.790 \mathrm{Da}$ to $59.746 \mathrm{Da}$. The Fourier Transform Infra Red spectra analysis showed that the depolymerization process of chitosan didn't change the functional group of chitosan. The affixation of depolymerized chitosan with molecular weight range 59.746-79.570 Da on cotton fabric which both continued with and without the dyeing process yielded excellent antibacterial properties as high as $99-100 \%$. The results of $N$-total value tests showed that the cotton fabric with affixation of chitosan molecular weight $79.500 \mathrm{Da}$ has the higher N-total value than with chitosan molecular weight $171.790 \mathrm{Da}$. The colour strength curves result showed that low molecular weight chitosan was compatible with the reactive dyes used in dyeing process and gave stronger colour in cotton fabric comparing with high molecular chitosan and without chitosan.

Keywords: chitosan, depolymerization, antibacterial properties, microwave oven

\section{PENDAHULUAN}

Beberapa penelitian aplikasi kitosan pada benang maupun kain kapas telah dilakukan untuk menghasilkan produk benang/kain yang bersifat antibakteri. Proses fiksasi kitosan pada benang/kain kapas dilakukan dengan cara memodifikasi struktur kimia kovalen serat kapas yang berupa selulosa sehingga terbentuk gugus aldehid dengan menggunakan oksidator natrium periodat. 
Kemudian gugus aldehid akan berikatan dengan gugus amina dari kitosan sehingga terjadi fiksasi kitosan pada serat kapas. ${ }^{1,2,3}$

Berat molekul (BM) dapat mempengaruhi sifat antibakteri dari kitosan. Penelitian sebelumnya menunjukkan bahwa pada konsentrasi asam asetat 50-100 ppm, kitosan dengan BM yang lebih rendah menghasilkan sifat antibakteri $E$. coli (gram negatif) yang lebih baik dibandingkan kitosan dengan BM yang lebih tinggi. ${ }^{4}$ Pengaruh BM kitosan terhadap aktivitas antibakteri yaitu bila BM naik maka penetrasi ke dalam inti sel menurun sehingga sifat antibakteri juga akan menurun atau dengan kata lain sifat antibakteri kitosan akan lebih baik bila BM kitosan diturunkan. Dalam penelitian lainnya juga dinyatakan bahwa aktivitas antibakteri yang dihasilkan oleh kitosan terhadap bakteri gram negatif terbukti lebih tinggi dengan menurunnya berat molekul, derajat asetilasi, dan $\mathrm{pH}$ dari kitosan. ${ }^{5}$ Namun dari beberapa penelitian terdahulu, pengaruh $\mathrm{BM}$ ini juga bervariasi terhadap sifat antibakteri yakni dipengaruhi oleh jenis bakteri (gram positif atau negatif) dan juga konsentrasi kitosan yang digunakan. ${ }^{6}$ Kitosan dengan berat molekul yang rendah dapat diaplikasikan lebih luas dengan rendahnya viskositas serta memiliki kelarutan yang lebih tinggi pada larutan netral yang juga akan memperluas aplikasinya baik sebagai antimikroba maupun antiiamur. dan zat antitumor. ${ }^{7}$

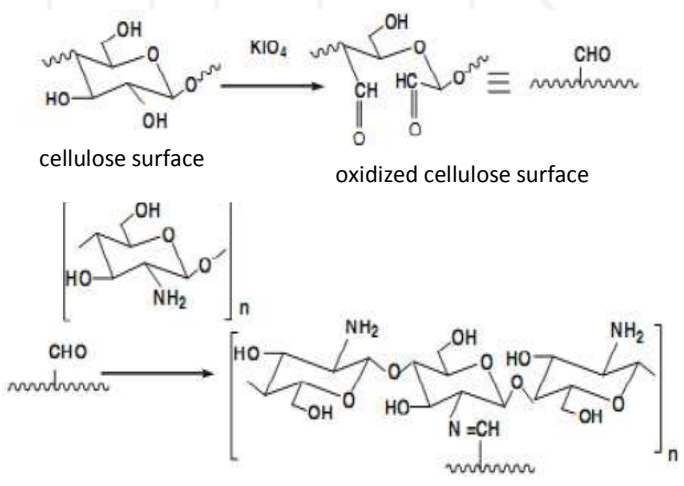

Gambar 1. Reaksi fiksasi kitosan pada selulosa ${ }^{2}$

Penurunan BM kitosan dapat dilakukan melalui proses depolimerisasi kitosan. Ada beberapa cara untuk melakukan depolimerisasi suatu polimer, yaitu secara kimia, fisik dan enzimatik. Depolimerisasi kitosan secara kimia dapat dilakukan dengan mengunakan asam kuat $\mathrm{H}^{+}$ hingga terjadi proses hidrolisis yang akan memotong rantai polimer kitosan atau dengan menambahkan asam nitrit $\left(\mathrm{HNO}_{2}\right)$ sehingga akan terjadi deaminasi yang juga dapat memotong rantai polimer kitosan. Cara kimia ini merupakan cara yang umum digunakan dan memerlukan waktu yang singkat untuk menghasilkan chitooligomer, tetapi mempunyai kelemahan karena biayanya yang relatif tinggi dengan hasil yang rendah serta teriadinva residu asam vano hersifat nolutan haoi lingkungan. Depolimerisasi kitosan cara fisik dapat dilakukan dengan radiasi (UV, $\gamma$ ), ultrasound, microwave dan perlakuan panas. Salah satu cara fisik yang telah dicoba adalah dengan radiasi gelombang mikro menggunakan oven microwave, yang akan menghasilkan oligomer kitosan. Cara fisik ini akan mengurangi dampak dari polusi terhadap lingkungan karena tidak menghasilkan residu bahan kimia. Cara lain untuk depolimerisasi polimer adalah menggunakan enzim. Degradasi kitosan dapat dilakukan menggunakan enzim chitinase, chitosanase, glucanase, lipase, dan beberapa protease. Beberapa enzim non-spesifik yaitu lysozyme, cellulose, amylase, papain, dan pectinase juga dapat mendegradasi kitosan. ${ }^{4,8}$

Dalam penelitian ini depolimerisasi kitosan dilakukan dengan cara fisik yaitu dengan memberi radiasi gelombang mikro menggunakan oven microwave Tingkat depolimerisasi yang terjadi akan dipengaruhi oleh waktu penyinaran dan daya (watt) yang diberikan. Dilakukan penyinaran dengan variasi waktu antara 5 menit hingga 25 menit dan daya 300 watt hingga 800 watt untuk mendapatkan BM kitosan hingga sekitar 50.000. Selama penyinaran akan terjadi reaksi sebagaimana ditunjukkan pada Gambar 2.

Radiasi gelombang mikro merupakan sumber energi panas yang telah digunakan dalam beragam reaksi sintesis. Pada proses depolimerisasi kitosan, adanya energi tersebut menyebabkan pemutusan ikatan kovalen dan ikatan glikosida antara molekulmolekul kitosan (GlcN dan GlcNAc) dan menghasilkan rantai polimer kitosan yang lebih pendek (chitooligomer) serta BM yang lebih rendah. Penambahan garam anorganik pada proses depolimerisasi dengan radiasi gelombang mikro juga memberikan efek penurunan BM kitosan. Energi panas dapat terabsorpsi secara langsung oleh molekul-molekul garam dan menyebabkan pemanasan ekstra pada larutan. BM kitosan dapat turun drastis dengan keberadaan garam (dari 100.000 Da menjadi $30.000 \mathrm{Da})$ dan pengaruh komposisi elektrolit yaitu $\mathrm{K}^{+}>\mathrm{Ca}^{2+}>\mathrm{Na}^{+}$ berdasarkan pada radius ionik dari logam. ${ }^{9}$

Pada penelitian ini dilakukan fiksasi kitosan pada kain kapas dengan variasi berat molekul kitosan. Hasil fiksasi kitosan pada kain kapas tersebut dianalisa terhadap sifat antibakteri, kemampuannya untuk dicelup, pengaruh terhadap nilai N-Total, dan pengaruh ketahanan bakteri terhadap pencucian berulang.

\section{METODE}

\section{Bahan}

Kain kapas dan bahan kimia grade teknis diperoleh dari pasaran, kitosan teknis diperoleh dari yang PT. Biotech Surindo Cirebon. Bahan kimia grade p.a diperoleh dari Merck. Data kitosan diounakan dineroleh dari certifikat nroduk vano 


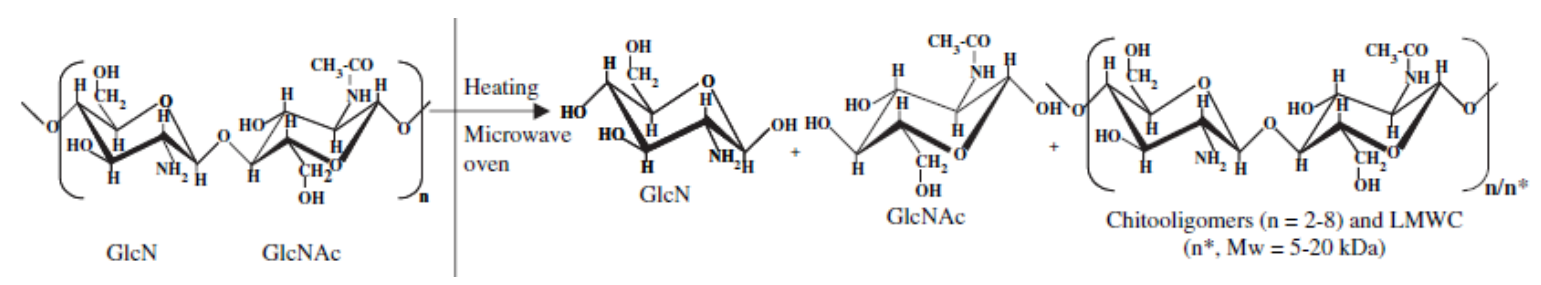

Gambar 2. Reaksi depolimerisasi kitosan dengan pemanasan oven microwave ${ }^{9}$

dikeluarkan oleh produsen dan dari hasil pengukuran. Kitosan berwarna putih ke kuningan (off white), ukuran partikel 20-30 \#, kadar air $<10$ $\%$, kadar abu <1,5 \%, pH 7-8, Derajat Deasetilasi (DD) sekitar 90\%, dan Berat Molekul (BM) $\quad 171.790 \quad \mathrm{Da}$ dari hasil pengukuran menggunakan Persamaan (1).

\section{Peralatan}

Peralatan yang digunakan di laboratorium meliputi mesin ekshaus, oven microwave. Mesin yang digunakan di industri meliputi mesin Jetdyeing, pengering Calander dan Stenter. Alat Brookfield viskometer digunakan untuk mengukur viskositas larutan kitosan, alat FTIR merek Shimadzu Prestige digunakan untuk analisa gugus fungsi kitosan dan kain kapas, dan alat spektrofotometer merek X-Rite untuk uji beda warna kain kapas hasil pencelupan.

\section{Cara depolimerisasi kitosan}

Cara penurunan berat molekul yang dilakukan yakni menggunakan radiasi gelombang mikro dan penambahan larutan elektrolit berupa garam anorganik. Depolimerisasi kitosan dilakukan untuk memperoleh kitosan dengan berat molekul yang bervariasi. Proses depolimerisasi dilakukan di laboratorium secara fisik dengan memanfaatkan gelombang mikro dari oven microwave. Kitosan dilarutkan dalam asam asetat $1 \%$ dan larutan $\mathrm{NaCl}$ $0,5 \mathrm{M}$ (rasio volume $=8: 2$ ), $\mathrm{CaCl}_{2} 0,1 \mathrm{M}$, dan $\mathrm{CaCl}_{2}$ $0,25 \mathrm{M}$ (rasio volume $=7: 3$ ). Kemudian larutan diradiasi di dalam oven microwave dengan variasi daya 300 watt, 550 watt, 650 watt dan 800 watt selama 5-25 menit. BM kitosan diukur melalui pengukuran viskositas larutan dan dihitung dengan menggunakan persamaan Mark Houwink (Persamaan 1). ${ }^{4}$

$$
\left[\eta=K \cdot m^{\mathrm{a}}\right] \ldots \ldots \ldots
$$

dimana

$$
\begin{array}{ll}
\eta & =\text { viskositas, } \mathrm{cps} \\
\mathrm{K} & =1,64 \times 10^{-30} \times \mathrm{DD}^{14} \\
\mathrm{a} & =-1,02 \times 10^{-2} \mathrm{DD}+1,82 \\
\mathrm{~m} & =\text { berat molekul, } \mathrm{Da} \\
\mathrm{DD} & =\text { derajat deasetilasi dalam persen }
\end{array}
$$

\section{Fiksasi kitosan pada kain kapas}

Aplikasi kitosan pada kain kapas dilakukan melalui cara kimia yaitu diawali dengan proses oksidasi kain kapas menggunakan natrium periodat hingga mempunyai gugus aldehid, dilanjutkan reaksi gugus aldehid tersebut dengan gugus amina dari kitosan, hingga terjadi fiksasi/penempelan kitosan pada kain kapas. Proses fiksasi dilakukan satu tahap dengan cara perendaman. ${ }^{2,3}$

\section{Pencelupan kain kapas terfiksasi kitosan}

Salah satu syarat zat antibakteri yang digunakan pada bahan tekstil adalah harus cocok (compatible) dengan zat kimia yang digunakan pada proses tekstil serta harus memiliki ketahanan terhadap proses pencelupan, pencucian dan pemanasan (setrika). Untuk memenuhi ketentuan tersebut, pada percobaan ini dilakukan proses pencelupan kain kapas yang telah terfiksasi kitosan $\mathrm{BM}$ tinggi $(\mathrm{BM}=171.790 \mathrm{Da})$ dan $\mathrm{BM}$ rendah $(\mathrm{BM}=79.500 \mathrm{Da})$ menggunakan zat warna reaktif.

Selain itu, uji pencucian berulang terhadap kain kapas hasil fiksasi dan pencelupan tersebut juga dilakukan untuk mengetahui pengaruh kitosan BM rendah pada ketahanan proses pencucian dan pemanasan (setrika). Sebelum proses pencelupan, dilakukan proses fiksasi kitosan pada kain kapas dengan 2 variasi BM kitosan yaitu BM $171.790 \mathrm{Da}$ dan BM 79.500 Da dengan cara ekshaus menggunakan mesin jet dyeing di industri tekstil.

Proses pencelupan dilakukan di industri menggunakan zat warna reaktif Novacron dengan kondisi proses sebagai berikut: Lemon S-3G $0,013 \%$ dan Drimaren Turquise $0,041 \%$. Zat pembantu $\mathrm{NaOH} 30 \mathrm{~g} / 1$, soda ash $13 \mathrm{~g} / 1$, chelating agent $0,5 \mathrm{~g} / 1$, anti crease $0,5 \mathrm{~g} / 1$. Temperatur celup $80^{\circ} \mathrm{C}$, waktu pencelupan 45 menit. Mesin celup yang digunakan adalah mesin jet dyeing, dengan proses pengeringan menggunakan Stenter dan Callander. ${ }^{3}$ Diagram alir penelitian yang dilakukan sebagaimana yang tercantum pada Gambar 3 .

\section{Pengujian}

Untuk mengetahui keberhasilan penelitian dilakukan pengujian ketahanan bakteri terhadap kain kapas hasil fiksasi menggunakan kitosan berbagai BM yang merupakan hasil depolimerisasi 


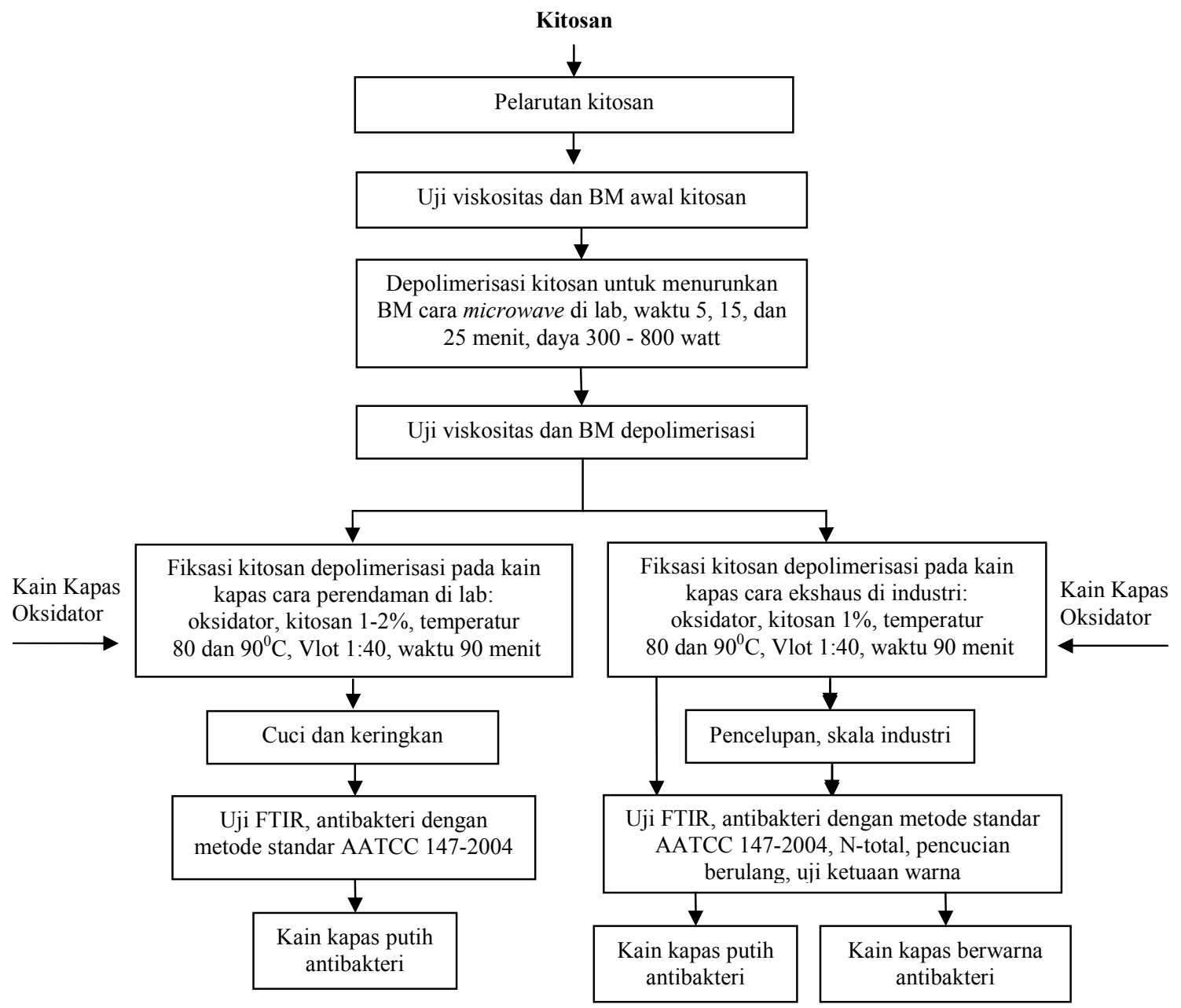

Gambar 3. Diagram alir penelitian

dan kain kapas kitosan tanpa depolimerisasi sebagai pembanding.

Uji ketahanan bakteri dilakukan dengan menggunakan standar AATCC 147-2004,,$^{10,11}$ uji Ntotal (jumlah kandungan nitrogen) dengan metode Kjehdahl, uji pencucian berulang, dan uji ketuaan warna dengan metode CIELab D65-10. ${ }^{12}$

\section{HASIL DAN PEMBAHASAN}

\section{Depolimerisasi kitosan}

Hasil penurunan BM kitosan dengan variasi berbagai komposisi pelarut dapat dilihat pada Gambar 4. Dari data hasil proses depolimerisasi kitosan yang disajikan pada Gambar 4a) sampai dengan Gambar 4d), terlihat bahwa pada semua jenis komposisi pelarut makin lama waktu pemanasan dengan oven microwave, depolimerisasi makin tinggi sehingga dihasilkan kitosan dengan berat molekul yang makin rendah. Demikian pula pengaruh peningkatan daya, makin tinggi daya yang diberikan umumnya memberikan depolimerisasi yang makin tinggi sehingga dihasilkan kitosan dengan berat molekul yang makin rendah.

Penggunaan campuran pelarut asam asetat 1\%: larutan $\mathrm{CaCl}_{2}$ 0,25 $\mathrm{M}=7: 3$ (rasio volume) memberikan hasil depolimerisasi kitosan yang terbaik. Dengan waktu pemanasan selama 15 menit, berat molekul kitosan awal yakni $171.790 \mathrm{Da}$ turun masing-masing menjadi sekitar $70.000 \mathrm{Da}$ dan 50.000 Da pada penggunaan daya oven microwave 300 watt dan 650 watt. Penambahan larutan elektrolit seperti $\mathrm{NaCl}$ dan $\mathrm{CaCl}_{2}$ (Gambar $4 \mathrm{~b}, 4 \mathrm{c}$, dan 4d) berpengaruh signifikan terhadap penurunan BM kitosan hasil depolimerisasi, jika dibandingkan dengan tanpa penggunaan elektrolit (Gambar 4a).

Penambahan garam anorganik mampu mempercepat proses depolimerisasi kitosan. Sifat dari larutan elektrolit yang memiliki muatan ion memudahkan proses penghantaran panas gelombang mikro dari media pelarut menuju molekul-molekul kitosan sehingga mempercepat proses depolimerisasi kitosan. Panas dari gelombang mikro melibatkan interaksi langsung 

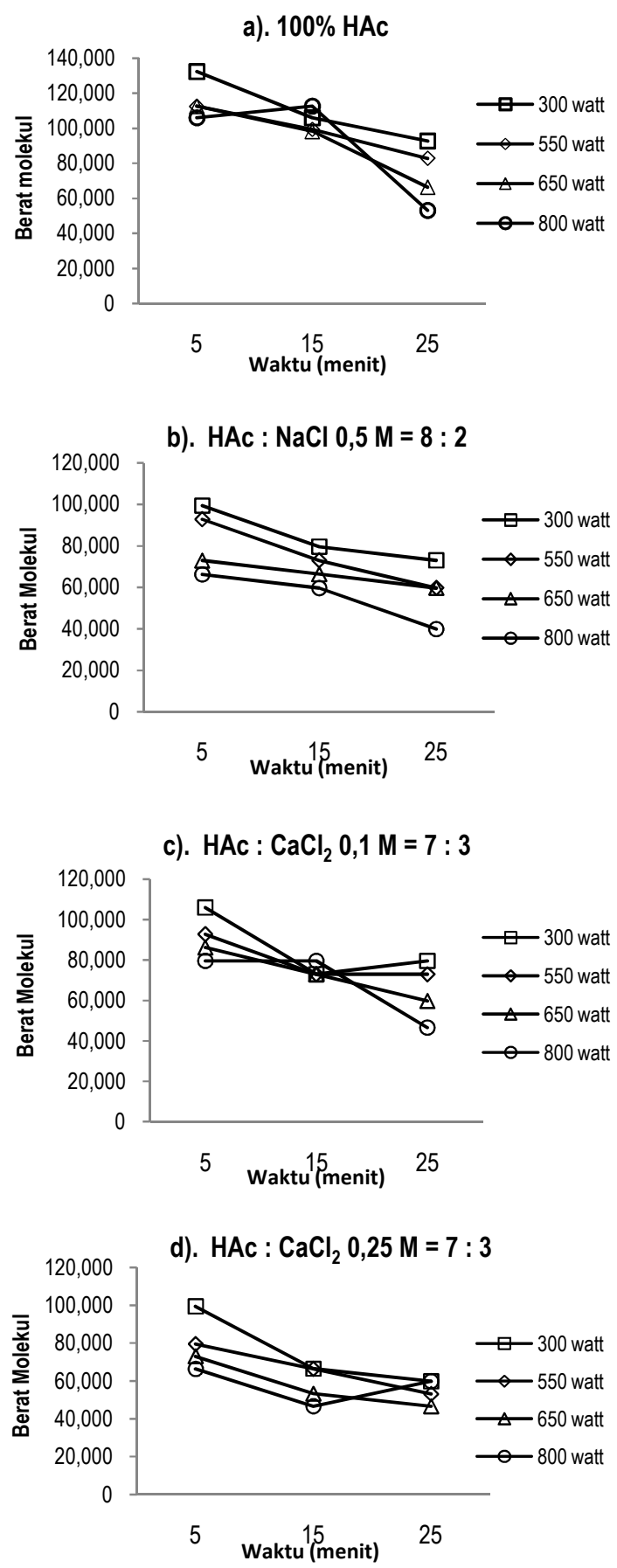

Gambar 4. Depolimerisasi kitosan dengan variasi jenis, konsentrasi, dan komposisi pelarut

dengan molekul-molekul penyerap panas sehingga menyebabkan penghantaran panas dari sumber gelombang mikro dan meningkatkan temperatur larutan. Penambahan garam elektrolit pada larutan kitosan menyebabkan peningkatan konduktivitas dan sangat berpengaruh bagi laju pemanasan. ${ }^{13}$

Pada penggunaan daya oven microwave 300650 watt dan rasio volume campuran pelarut asam asetat $1 \%: \mathrm{CaCl}_{2}=7: 3$, penambahan $\mathrm{CaCl}_{2}$ dengan konsentrasi yang lebih tinggi yakni $0,25 \mathrm{M}$ ternyata lebih signifikan dalam menurunkan berat molekul kitosan dibandingkan dengan penambahan $\mathrm{CaCl}_{2}$ $0,1 \mathrm{M}$. Hal ini kemungkinan dikarenakan perbedaan kekuatan ionik yang dihasilkan dipengaruhi oleh konsentrasi larutan elektrolit. Semakin tinggi konsentrasi elektrolit yang ditambahkan maka akan semakin tinggi pula kekuatan ioniknya. Namun pada waktu pemanasan yang lebih lama yakni 25 menit dan pada daya yang lebih tinggi yakni 800 watt, penggunaan campuran pelarut asam asetat $1 \%: \mathrm{CaCl}_{2}$ 0,25 $\mathrm{M}$ menyebabkan kitosan menjadi rusak karena pelarut yang lebih cepat menguap sehingga kitosan lebih cepat hangus. Pada penggunaan daya 800 watt, lama waktu pemanasan yang menghasilkan $\mathrm{BM}$ terendah pada rasio volume campuran pelarut asam asetat $1 \%: \mathrm{CaCl}_{2} 0,25 \mathrm{M}=$ 7:3 yakni 15 menit. Berdasarkan hasil tersebut, maka proses penurunan BM kitosan yang optimum dipilih pada penggunan daya yang lebih rendah yakni 300-650 watt dan campuran pelarut asam asetat 1\%: larutan $\mathrm{CaCl}_{2}$ 0,25 $\mathrm{M}=7: 3$ (rasio volume) selama 15 menit.

\section{Hasil uji FTIR}

Pengujian menggunakan FTIR dilakukan untuk mengkarakterisasi kitosan serta kain kapas yang telah terfiksasi kitosan. Pengujian FTIR dilakukan terhadap kitosan awal $(\mathrm{BM}=171.790$ Da) dan kitosan yang telah mengalami proses depolimerisasi $(\mathrm{BM}=79.500 \mathrm{Da})$. Data hasil uji FTIR kitosan disajikan pada Gambar 5.

Dari spektra FTIR (Gambar 5), kitosan BM 171.790 Da dan kitosan BM 79.500 Da memperlihatkan kesamaan puncak-puncak, yaitu pada bilangan gelombang $3300-3500 \mathrm{~cm}^{-1}$ menunjukkan gugus $\mathrm{OH}^{-}$dan $\mathrm{NH}_{2}, 1250-1325 \mathrm{~cm}^{-1}$ untuk gugus $\mathrm{C}-\mathrm{N}$ aromatik; $1641 \mathrm{~cm}^{-1}$ untuk gugus $\mathrm{C}=\mathrm{O}$ amida; $1152 \mathrm{~cm}^{-1}$ untuk gugus $\mathrm{C}-\mathrm{H}$, $1094 \mathrm{~cm}^{-1}$ untuk gugus C-O dari polisakarida, 1020 $\mathrm{cm}^{-1}$ untuk gugus $\mathrm{C}-\mathrm{N}$ alifatik, serta 660 dan 910 $\mathrm{cm}^{-1}$ menunjukkan adanya gugus amina primer dan sekunder.

Kesamaan puncak tersebut menunjukkan bahwa tidak ada perbedaan antara kitosan BM tinggi dengan kitosan BM rendah hasil depolimerisasi, dikarenakan proses depolimerisasi hanya memutus rantai polimer menjadi lebih pendek sehingga berat molekul menurun tetapi tidak merubah struktur molekul kitosan. Luas puncak spektra kitosan BM rendah pada bilangan gelombang $2800 \mathrm{~cm}^{-1}$ (gugus C-H) terlihat lebih kecil jika dibandingkan dengan kitosan $\mathrm{BM}$ tinggi. Hal ini menunjukkan bahwa proses depolimerisasi menunjukkan bahwa fiksasi kain kapas dengan konsentrasi kitosan $2 \%$ yang memiliki rentang BM menyebabkan berkurangnya jumlah ikatan $\mathrm{C}-\mathrm{H}$ pada rantai polimer kitosan. Gambar 6 merupakan spektra FTIR dari kain kapas yang terfiksasi kitosan BM 171.790 Da dan kitosan BM 79.500 Da. 


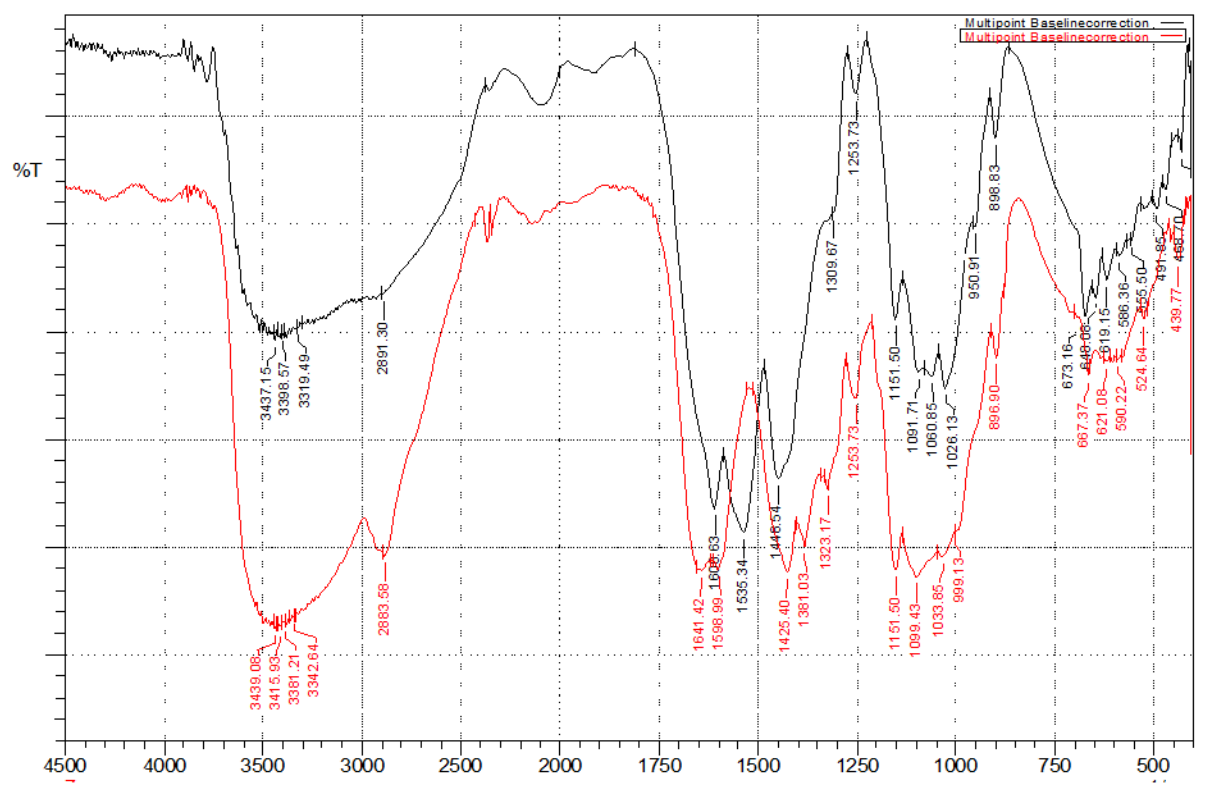

Gambar 5. Spektra FTIR kitosan BM 171.790 Da (kurva bawah) dan kitosan BM 79.500 Da (kurva atas)

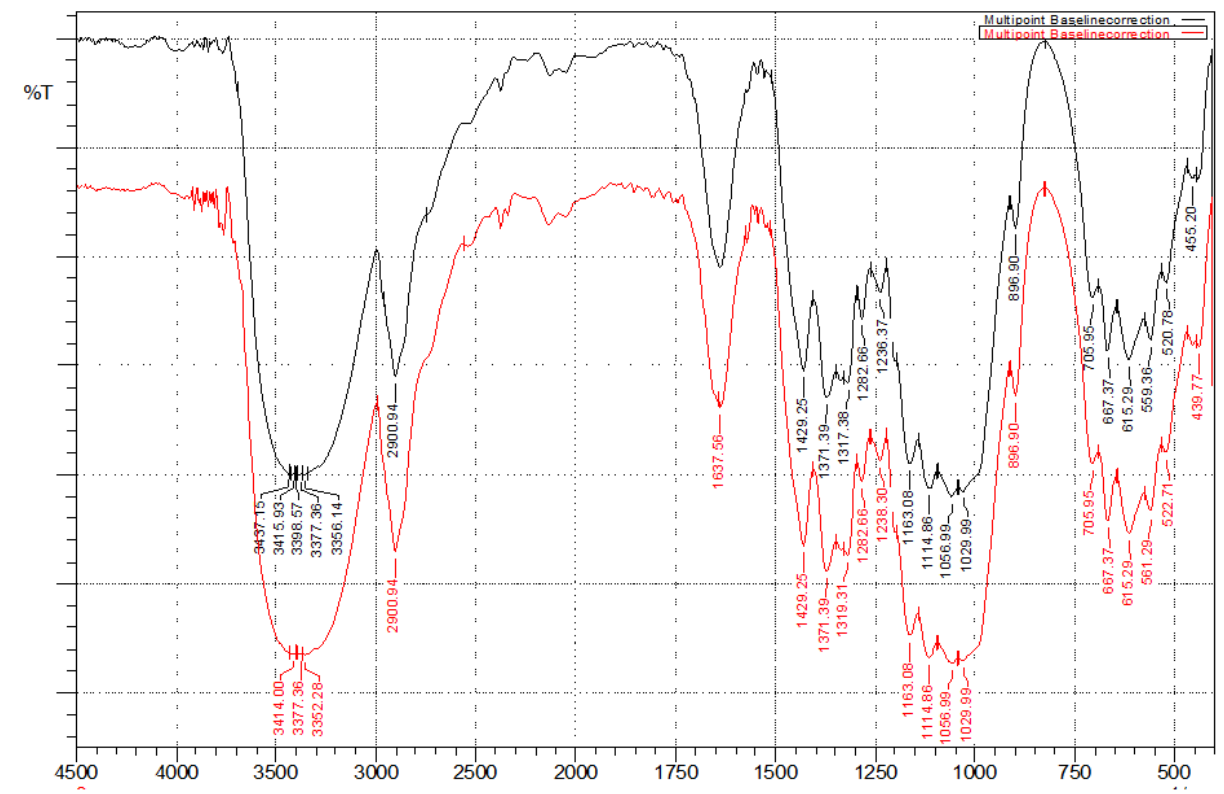

Gambar 6. FTIR kain kapas fiksasi kitosan BM 171.790 Da (kurva bawah) dan kitosan BM 79.500 Da (kurva atas)

Gambar tersebut menunjukkan kesamaan puncakpuncak, yaitu pada bilangan gelombang 3300-3500 $\mathrm{cm}^{-1}$ menunjukkan gugus $\mathrm{OH}^{-}$dan $\mathrm{NH}_{2}$, serta 1325 $\mathrm{cm}^{-1}$ juga untuk amina; pada $1730 \mathrm{~cm}^{-1}$ terdapat absorpsi lemah dari stretching vibrasi $\mathrm{C}=\mathrm{O}$ dari gugus aldehida dan $1641 \mathrm{~cm}^{-1}$ untuk gugus $\mathrm{C}=\mathrm{N}$ yang terbentuk antara gugus aldehida dan kitosan yang menunjukkan terjadinya fiksasi kitosan pada kain kapas tersebut. ${ }^{2}$ Dengan adanya kesamaan karakteristik puncak-puncak tersebut, menunjukkan bahwa proses depolimerisasi tidak mengubah struktur kimia dari kitosan yang terfiksasi pada kain kapas.

\section{Hasil uji sifat antibakteri}

Pengujian sifat antibakteri kain kapas yang telah terfiksasi oleh kitosan dengan berbagai variasi BM telah dilakukan dengan hasil sebagaimana yang tertera pada Tabel 1. Data pada Tabel 1171.000 hingga $59.000 \mathrm{Da}$, pada suhu $80^{\circ} \mathrm{C}$ maupun $90^{\circ} \mathrm{C}$, mempunyai ketahanan terhadap bakteri mendekati $100 \%$ dengan waktu inkubasi selama 48 jam. 
Kitosan hasil depolimerisasi (rentang BM 59.000$79.000 \mathrm{Da})$ maupun yang tidak mengalami depolimerisasi (BM 171.000 Da) sama-sama memiliki ketahanan yang baik terhadap bakteri Escherichia coli dan Staphylococcus aureus. Namun pada hasil uji ketahanan terhadap bakteri Escherichia coli, pada suhu fiksasi kitosan $90^{\circ} \mathrm{C}$ terlihat kecenderungan peningkatan sifat antibakteri sebesar $0,11 \%$ seiring dengan menurunnya $\mathrm{BM}$ kitosan (BM 171.790 Da menjadi 72.694 Da).

Kecenderungan hasil uji sifat antibakteri yang hampir sama antara kitosan terdepolimerisasi dengan yang tidak terdepolimerisasi kemungkinan dikarenakan konsentrasi kitosan yang digunakan adalah konsentrasi yang maksimum untuk menghasilkan sifat antibakteri. Hasil penelitian terdahulu, ${ }^{9}$ mengemukakan bahwa pada konsentrasi kitosan $1 \%$, kitosan dengan variasi berat molekul mulai dari $<5 \mathrm{kDa}$ hingga $305 \mathrm{kDa}$ menghasilkan aktivitas antibakteri yang maksimum yakni $100 \%$ baik untuk jenis bakteri gram positif maupun gram negatif. Namun berbeda dengan konsentrasi kitosan yang lebih rendah yakni $0,25-0,75 \%$, penurunan BM kitosan menyebabkan aktivitas antibakteri gram negatif meningkat. Sebaliknya, pada bakteri gram positif, aktivitas antibakterinya menurun seiring dengan penurunan BM. ${ }^{6}$

Mekanisme aktivitas antibakteri dapat dibedakan menjadi 2 tergantung dari jenis bakteri gram positif atau gram negatif. Pada bakteri gram positif ( $S$. aureus), kitosan teradsorpsi pada permukaan sel dan membentuk membran polimer yang dapat menghambat nutrisi memasuki sel-sel bakteri. Sementara pada bakteri gram negatif
(E. coli), kitosan dengan berat molekul yang lebih rendah lebih mudah memasuki sel bakteri melalui proses permeasi. Muatan positif dari kitosan dapat mengikat permukaan bakteri gram negatif dan merusak membran sel serta meningkatkan permeabilitasnya. Kitosan juga mampu menyerap substansi sel bakteri yang bersifat elektronegatif dan menyebabkan terjadinya flokulasi sehingga mengganggu aktivitas fisiologis bakteri dan akhirnya membunuh bakteri tersebut. ${ }^{6,14}$

Tabel 2 menunjukkan perbandingan hasil uji ketahanan bakteri dan kandungan N-total dari kain kapas yang terfiksasi kitosan BM 171.790 Da dan BM 79.500 Da yang tidak dicelup maupun yang dicelup zat warna reaktif. Sumber data ketahanan bakteri pada kitosan BM 171.790 Da diambil dari penelitian terdahulu. ${ }^{3}$ Pada penggunaan konsentrasi kitosan yang diturunkan menjadi $1 \%$, kain kapas terfiksasi kitosan BM 79.500 Da yang kemudian dicelup dengan zat warna reaktif menghasilkan ketahanan bakteri $E$. coli sedikit lebih rendah yakni $0,3 \%$ dibandingkan dengan yang tidak mengalami proses pencelupan. Namun demikian, setelah proses pencelupan zat warna reaktif, ketahanan bakteri yang dihasilkan oleh kitosan BM 79.500 Da sama dengan kitosan BM 171.790 Da yakni sebesar 99\%. Hasil uji ketahanan terhadap bakteri $S$. aureus baik dengan kitosan BM 79.500 Da atau BM 171.790 Da serta dilanjutkan dengan pencelupan ataupun tidak, seluruhnya menghasilkan ketahanan bakteri yang maksimum sebesar $100 \%$. Dari data tersebut, dapat diketahui bahwa proses depolimerisasi kitosan tidak mengubah sifat ketahanan bakteri dari kain kapas

Tabel 1. Ketahanan bakteri kain kapas fiksasi kitosan berbagai BM pada suhu $80^{\circ} \mathrm{C}$ dan $90^{\circ} \mathrm{C}$

\begin{tabular}{|c|c|c|c|c|c|c|c|}
\hline \multirow{2}{*}{\multicolumn{2}{|c|}{$\begin{array}{l}\text { Keterangan sampel } \\
\text { dan perlakuan }\end{array}$}} & \multicolumn{6}{|c|}{ Jumlah bakteri } \\
\hline & & \multicolumn{3}{|c|}{ Bakteri Escherichia coli } & \multicolumn{3}{|c|}{ Bakteri Staphylococcus aureus } \\
\hline $\begin{array}{l}\text { Berat molekul } \\
\text { (Da) }\end{array}$ & $\begin{array}{c}\text { Suhu } \\
\left({ }^{\circ} \mathrm{C}\right)\end{array}$ & $\begin{array}{c}\text { Inkubasi } 0 \\
\text { jam }\end{array}$ & $\begin{array}{c}\text { Inkubasi } 48 \\
\text { jam }\end{array}$ & $\% \mathbf{R}$ & $\begin{array}{c}\text { Inkubasi } 0 \\
\text { jam }\end{array}$ & $\begin{array}{c}\text { Inkubasi } 48 \\
\text { jam }\end{array}$ & $\% \mathbf{R}$ \\
\hline$*)$ & - & 550.000 .000 & 545.000 .000 & 0,91 & 1.070 .000 .000 & 1.060 .000 .000 & 0,93 \\
\hline 171.790 & 80 & 1.058 .500 .000 & 6.600 & 99,99 & 968.200 .000 & 60.000 & 99,99 \\
\hline 79.570 & 80 & 550.000 .000 & 1.325 .000 & 99,8 & 1.070 .000 .000 & 144.000 & 99,99 \\
\hline 72.964 & 80 & 1.058 .500 .000 & 115.117 & 99,99 & 968.200 .000 & 73.840 & 99,99 \\
\hline 66.356 & 80 & 1.058 .500 .000 & 70.103 & 99,99 & 968.200 .000 & 46.330 & 99,99 \\
\hline 59.746 & 80 & 550.000 .000 & 40.000 & 99,99 & 1.070 .000 .000 & 21.500 & 99,99 \\
\hline 171.790 & 90 & 1.058 .500 .000 & 1.620 .000 & 99,8 & 968.200 .000 & 73.000 & 99,99 \\
\hline 79.570 & 90 & 550.000 .000 & 1.230 .000 & 99,8 & 1.070 .000 .000 & 1.170 .000 & 99,99 \\
\hline 72.964 & 90 & 38.400 .000 .000 & 850.000 & 99,99 & 15.700 .000 .000 & 360.000 & 99,99 \\
\hline 66.356 & 90 & 1.058 .500 .000 & 2.250 & 99,99 & 968.200 .000 & 52.000 & 99,99 \\
\hline 59.746 & 90 & 21.000 .000 & 3.000 & 99,99 & 20.000 .000 & 2.500 & 99,99 \\
\hline
\end{tabular}

Keterangan: Konsentrasi kitosan 2\%, kondisi proses fiksasi pada Vlot 1:40 dan waktu 90 menit

*) Kain blanko (tanpa kitosan) 
Tabel 2. Ketahanan bakteri dan kandungan N-total kain kapas fiksasi kitosan yang dicelup dan tidak dicelup warna

\begin{tabular}{|c|c|c|c|c|c|c|c|c|c|c|}
\hline \multirow{2}{*}{$\begin{array}{l}\text { Jenis } \\
\text { kain }\end{array}$} & \multirow{2}{*}{$\begin{array}{c}\text { BM } \\
\text { Kitosan } \\
\text { (Da) }\end{array}$} & \multirow[b]{2}{*}{ Celup } & \multicolumn{3}{|c|}{ Bakteri Escherichia coli } & \multicolumn{3}{|c|}{ Bakteri Staphylococcus aureus } & \multicolumn{2}{|c|}{ N-Total } \\
\hline & & & $\begin{array}{c}\text { Inkubasi } \\
\text { 0 jam }\end{array}$ & $\begin{array}{c}\text { Inkubasi } \\
48 \text { jam }\end{array}$ & $\% \mathrm{R}$ & $\begin{array}{c}\text { Inkubasi } \\
\text { 0 jam }\end{array}$ & $\begin{array}{c}\text { Inkubasi } \\
48 \text { jam }\end{array}$ & $\% \mathrm{R}$ & $\%$ & $\mathrm{mg} / \mathrm{kg}$ \\
\hline \multirow{4}{*}{$\begin{array}{c}\text { Kain tipis, } \\
\text { gramasi }= \\
105,9 \\
\mathrm{~g} / \mathrm{m}^{2}\end{array}$} & 171.790 & Tidak & 74.000 .000 & 710.000 & 99,0 & 65.300 .000 & 0 & 100 & 0,05 & 544 \\
\hline & 79.500 & Tidak & 74.000 .000 & 510.000 & 99,3 & 65.300 .000 & 0 & 100 & 0,07 & 761 \\
\hline & 171.790 & Ya & 74.000 .000 & 770.000 & 99,0 & 65.300 .000 & 0 & 100 & 0,03 & 296 \\
\hline & 79.500 & Ya & 74.000 .000 & 770.000 & 99,0 & 65.300 .000 & 0 & 100 & 0,05 & 479 \\
\hline
\end{tabular}

Keterangan: Kondisi proses fiksasi pada konsentrasi kitosan 1\%, Vlot 1:40, waktu 90 menit

Tabel 3. Uji antibakteri kain kapas fiksasi kitosan setelah pencucian berulang

\begin{tabular}{|c|c|c|c|c|c|c|c|c|}
\hline \multirow{2}{*}{ Jenis kain } & \multirow{2}{*}{ Kode sampel } & \multirow{2}{*}{$\begin{array}{l}\text { Pencucian } \\
\text { di } \\
\text { Laborato- } \\
\text { rium }\end{array}$} & \multicolumn{3}{|c|}{ Bakteri Escherichia coli } & \multicolumn{3}{|c|}{ Bakteri Staphylococcus aureus } \\
\hline & & & $\begin{array}{c}\text { Inkubasi } \\
0 \text { jam }\end{array}$ & $\begin{array}{c}\text { Inkubasi } \\
48 \text { jam }\end{array}$ & $\begin{array}{l}\% \\
\text { R }\end{array}$ & $\begin{array}{c}\text { Inkubasi } \\
0 \text { jam }\end{array}$ & $\begin{array}{c}\text { Inkubasi } \\
48 \text { jam }\end{array}$ & $\% \mathbf{R}$ \\
\hline \multirow{3}{*}{$\begin{array}{l}\text { Kain tipis, } \\
\text { gramasi }= \\
105,9 \mathrm{~g} / \mathrm{m}^{2}\end{array}$} & kitosan & $1 \mathrm{X}$ & 72.510 .000 & 797.610 & 98,9 & 116.910 .000 & 0 & 100 \\
\hline & $\begin{array}{l}\text { depolimerisasi } \\
\text { (BM 79.500 Da) }\end{array}$ & $2 x$ & 72.510 .000 & 870.120 & 98,8 & 116.910 .000 & 67.760 & 99,9 \\
\hline & $1 \%+$ warna & $3 X$ & 72.510 .000 & 942.630 & 98,7 & 116.910 .000 & 92.111 & 99,9 \\
\hline
\end{tabular}

dan zat warna reaktif cocok untuk digunakan bersama kitosan dengan tidak menghilangkan sifat ketahanan bakterinya.

Hasil uji kandungan N-Total (total nitrogen) terhadap kain kapas fiksasi kitosan BM 79.500 Da lebih tinggi dibandingkan dengan kitosan BM $171.790 \mathrm{Da}$, baik dengan ataupun tanpa proses pencelupan warna. Hal ini menunjukkan bahwa dengan BM yang lebih rendah terbukti lebih banyak jumlah kitosan yang dapat terikat pada kain kapas. Nilai N-Total ini menunjukkan keberadaan gugus amino yang merupakan karakteristik dari kitosan. ${ }^{2}$

Hasil uji ketahanan bakteri terhadap pencucian kain berulang disajikan pada Tabel 3 . Dari hasil tersebut diketahui bahwa kain dengan fiksasi kitosan BM 79.500 Da setelah dicuci hingga 3 kali (setara dengan 15 kali pencucian rumah tangga) masih menghasilkan ketahanan bakteri yang baik walaupun terdapat sedikit penurunan. Hasil ini serupa dengan hasil pencucian kain kapas yang difiksasi dengan kitosan yang tidak terdepolimerisasi pada penelitian sebelumnya, ${ }^{3}$ yang membuktikan bahwa terjadi ikatan kimia antara kitosan dan selulosa sehingga menghasilkan ikatan yang kuat.

\section{Hasil pencelupan warna}

Hasil pencelupan warna dievaluasi dengan pengujian ketuaan warna yang direpresentasikan dengan nilai $\% \mathrm{R}$ (\% reflektansi) terhadap sampel kain kapas tanpa kitosan, kain kapas kitosan BM tinggi (171.790 Da), dan kain kapas kitosan BM rendah $(79.500 \mathrm{Da})$.
Hasil pengujian ketuaan warna ditunjukkan pada Gambar 7. Dari kurva CIELab tersebut terlihat bahwa kurva \%R (\% reflektansi) kain kapas tanpa kitosan yang dicelup hampir berhimpit dengan kain kapas kitosan BM 171.790 Da dan kain kapas kitosan BM 79.500 Da yang dicelup. Bentuk ketiga kurva yang hampir berhimpit tersebut dengan karakteristik puncak pada panjang gelombang yang sama menunjukkan bahwa baik kain kapas kitosan BM tinggi maupun BM rendah dapat dicelup karena menghasilkan arah warna yang sama dengan kain kapas tanpa kitosan. Hal ini membuktikan bahwa kitosan cocok (compatible) dengan zat warna reaktif yang digunakan pada proses pencelupan.

Pada panjang gelombang sekitar $675 \mathrm{~nm}$ yang merupakan panjang gelombang penyerapan warna maksimum, diperoleh nilai $\% \mathrm{R}$ kain kapas kitosan BM tinggi yakni 36,43\%, sedangkan \%R kain kapas kitosan BM rendah yakni 33,57\%. Kain kapas tanpa kitosan menghasilkan nilai \% R yang hampir sama dengan kitosan BM tinggi yakni $36,14 \%$ (kurva terlihat berhimpit). Berdasarkan hasil perbandingan nilai $\% \mathrm{R}$ tersebut, dapat diketahui bahwa kitosan $\mathrm{BM}$ rendah ternyata memberikan penyerapan warna yang lebih tinggi. Nilai \%R yang lebih rendah menunjukkan bahwa berkas cahaya yang dipantulkan oleh warna pada kain kapas kitosan BM rendah lebih sedikit jika dibandingkan dengan kain kapas tanpa kitosan dan kain kapas kitosan BM tinggi.

Hal ini menunjukkan bahwa kitosan BM rendah mampu menghasilkan warna yang lebih tua 


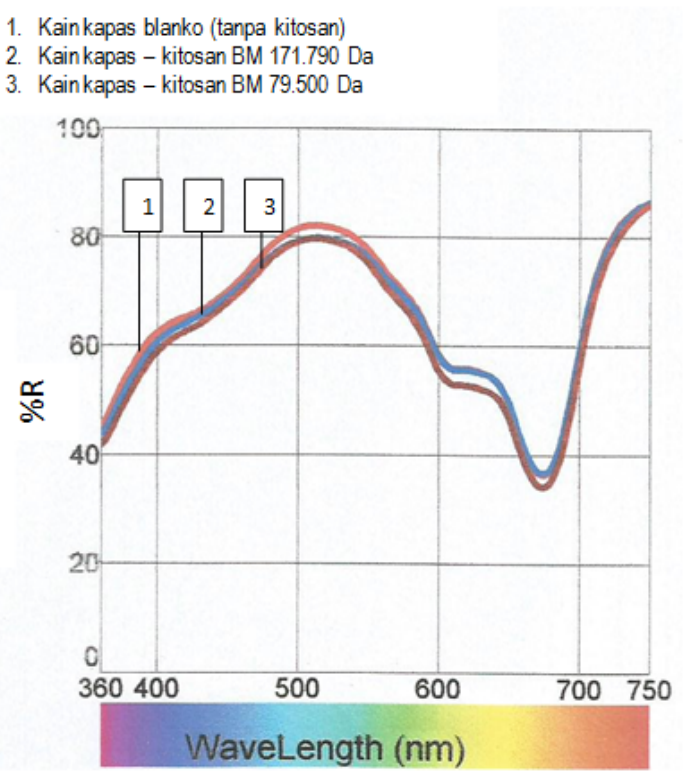

Gambar 6. Kurva CIE lab hasil pencelupan warna pada kain kapas

dibandingkan dengan kitosan $\mathrm{BM}$ tinggi dan tanpa kitosan.

\section{KESIMPULAN}

Proses depolimerisasi kitosan dengan cara fisik menggunakan radiasi gelombang mikro telah berhasil menurunkan berat molekul kitosan dari 171.790 hingga yang terendah yakni $59.746 \mathrm{Da}$ pada rentang daya 300-650 watt selama 15 menit dengan rasio volume campuran pelarut asam asetat $1 \%: \mathrm{CaCl}_{2} \quad 0,25 \mathrm{M}=7: 3$. Hasil uji FTIR menunjukkan bahwa proses depolimerisasi kitosan tidak mengubah gugus fungsi dari kitosan. Fiksasi kitosan dengan konsentrasi sebesar $2 \%$ pada kain kapas menghasilkan ketahanan bakteri yang maksimum yakni $99-100 \%$, baik dengan kitosan yang tidak terdepolimerisasi (BM $171.790 \mathrm{Da})$ maupun dengan kitosan yang terdepolimerisasi (BM 59.746 - 79.570 Da). Penggunaan kitosan BM rendah (79.500 Da) dengan penurunan konsentrasi menjadi $1 \%$ sebagai zat antibakteri pada kain kapas, baik yang dicelup zat warna reaktif maupun tidak, sama-sama menghasilkan aktivitas antibakteri yang mendekati $100 \%$ dan menghasilkan nilai N-Total yang lebih tinggi dibandingkan kitosan BM 171.790 Da. Hasil uji ketahanan bakteri terhadap pencucian berulang pada kain kapas terfiksasi kitosan BM rendah menunjukkan sifat antibakteri yang masih baik hingga 15 kali pencucian rumah tangga. Kitosan BM yang rendah telah terbukti cocok (compatible) dengan zat warna reaktif pada proses pencelupan dan menghasilkan warna yang lebih tua dilihat dari nilai \%R kain kapas kitosan BM rendah hasil celup yang lebih rendah jika dibandingkan dengan kain kapas kitosan BM tinggi dan kain kapas tanpa kitosan.

\section{PUSTAKA}

${ }^{1}$ Shanmugasundaran, O. L. (2006). Chitosan Coated Cotton Yarn and It's Effect on Antimicrobial Activity, Journal of Textile Apparel Technology and Management, 5 (3): 1-6.

${ }^{2}$ Ramadan, M.A., Samy, S., Abdulhady, M., and Hebeish, A.A. (2011). Eco-Friendly Pretreatment of Cellulosic Fabrics with Chitosan and Its Influence on Dyeing Efficiency. In. Emiye Akcakola Kumbasar (Ed.), Natural Dye (3-12), In Tech.

${ }^{3}$ Winiati, W., Wahyudi T., Yulina, R., Mulyawan, A.S., dan Septiani., W. (2014). Fiksasi Kitosan pada Kain Kapas sebagai Antibakteri, Jurnal Ilmiah Arena Tekstil, 29 (1): 25-36.

${ }^{4}$ Liu, N., et.al. (2006). Effect of MW and Concentration of Chitosan on Antibacterial Activity of Escherichia coli, Carbohydrate Polymers, 64 : 60-65

${ }^{5}$ Younes, Islem, Sellimi, S., Rinaudo, M., Jellouli, K., Nasri, M. (2014). Influence of acetylation degree and molecular weight of homogeneous chitosans on antibacterial and antifungal activities, International Journal of Food Microbiology, 185: 57-63.

${ }^{6}$ Zheng, Lian Y., Zhu, Jiang F. (2003). Study on antimicrobial activity of chitosan with different molecular weights, Carbohydrate Polymers, 54: 527-530.

${ }^{7}$ Zamani, Akram, Taherzadeh, M. J. (2010). Production of Low Molecular Weight Chitosan by Hot Dilute Sulfuric Acid, BioResources, 5 (3), 1554-1564.

${ }^{8}$ Tishchenko, Galina, dkk. (2011). Low-molecularweight chitosans: Preparation and characterization, Carbohydrate Polymers, 86: 1077-1081.

${ }^{9}$ Prashanth, K.V.H. and Tharanathan, R.N. (2007). Chitin/chitosan: Modifications and Their Unlimited Application Potential-An Overview, Trens in Food Science \& Technology, 18: 117131.

${ }^{10}$ Rajendran, R., et.al. (2012). Synthesis and Characterization of Neem Chitosan Nanocomposites for Development of Antimicrobial Cotton Textiles. Journal of Engineering Fibers and Fabrics, 7 (1): 136141

${ }^{11}$ AATCC Test Method 147-1998, Antibacterial Activity Assessment of Textile Materials, AATCC Technical Manual, 2004.

${ }^{12}$ Anonim. (2012). Color iQC and Color iMatch, Color Calculation Guide, x-rite Pantone, Version 8.0 , halaman 8 . 
${ }^{13}$ Xing, Ronge, dkk. (2005). Salt-assisted acid hydrolysis of chitosan to oligomers under microwave irradiation, Carbohydrate Research, 340: 21502153.
${ }^{14}$ Fouda M.M.G., Abdel Halim E.S., Al-Deyab, S. (2013). Antibacterial Modification of Cotton Using Nanotechnology. Carbohydrate Polymers, 92: 943-954. 